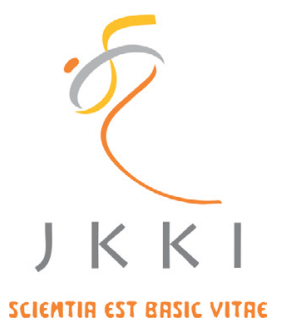

Jurnal Kedokteran dan Kesehatan Indonesia

Indonesian Journal of Medicine and Health

Journal homepage : https://journal.uii.ac.id/JKKI

\title{
Protein hydrolysate as a functional food for chronic kidney disease
}

Meilinah Hidayat*1, Sijani Prahastuti ${ }^{1}$, Andreanus Andaja Soemardji ${ }^{2}$, Mohammad Yusuf ${ }^{3}$ and Khomaini

Hasan $^{4}$

${ }^{1}$ Faculty of Medicine, Universitas Kristen Maranatha Bandung, Indonesia,

${ }^{2}$ School of Pharmacy, Institut Teknologi Bandung, Indonesia

${ }^{3}$ Research Center for Biotechnology and Bioinformatics, Universitas Padjadjaran, Bandung, Indonesia,

${ }^{4}$ Faculty of Medicine, Universitas Jenderal Achmad Yani, Cimahi, Indonesia



\section{GUEST EDITORIAL}

\begin{tabular}{l}
\hline ART ICLE INFO \\
\hline $\begin{array}{l}\text { *Corresponding author: } \\
\text { mellahidayat@yahoo.com }\end{array}$
\end{tabular}

he progress of science and technology in the last few decades has improved the welfare and health of humanity. Invention in the fields of medicine, biochemistry, nutrition and food technology show their role in overcoming and managing various diseases through the role of

DOI : 10.20885/JKKI.Vol10.Iss3.art1 functional food. The discovery of the process and manufacture of protein hydrolysate shows a pivotal role in fulfill the nutritional needs of several

Copyright @2019 Authors. This is an open access article distributed under the terms of the Creative Commons Attribution-NonCommercial $\quad 4.0$ International Licence (http:// creativecommons.org/licences/ by-nc/4.0/). diseases. Because the structure of the protein will determines its function, then bioinformatics take an important role of in preparing functional food production for the future.

Protein hydrolysate, mixtures of amino acids obtained from the hydrolysis process made by separating proteins from acids, alkalis, or enzymes. Hydrolysate nutrients preparations that is produced from original ingredients in the form of amino acids that build it, are commonly used as a provider of nutrients and special dietary fluids for patients who are unable to consume ordinary food protein. ${ }^{1}$

Its use as a protein supplement, among others, as energetic drinks, geriatric products, sports nutrition or weight control diets. While its use in the clinical field, among others, as functional food for patients with phenylketonuria (PKU), hypoallergenic infant, acute and chronic liver disease, short bowel syndrome, crohn's disease, pancreatitis and ulcerative colitis. ${ }^{2}$

In the academic literature, functional food is defined as food that is intended to be eaten as part of a daily diet and contains biologically active components that have the potential to improve health or reduce the risk of disease. ${ }^{3}$ In other words, a modified food which is provides benefits to health in addition to the benefits of it's nutritional content. Functional food is one of the mainstays in efforts to maintain public health, which has effect of reducing health costs, increasing productivity and fostering people's economy. Three important things to determine functional food through research are: bioactive compounds, biological availability and biomarkers of valid scientific evidence which states that a food has good physiological effects, which are beneficial to health. ${ }^{4}$

Preliminary studies indicate that protein hydrolysate is more effectively used than whole protein or amino acids. In addition, they promote a strong insulinotropic effect, which reduces protein breakdown and increases the absorption of muscle and branched-chain amino acid tissue. These effects contribute to the benefits of protein hydrolysate to increase repair of tissue damage caused by surgery, ulcers, burns, and muscle damage exercises. There is evidence that protein hydrolysate might be useful to repair tissue damage in some diseases, however additional research is needed to further examine the various roles of protein hydrolysate in this process. ${ }^{5}$ 
Most of CKD patients die from cardiovascular complications arising from high blood pressure associated with kidney damage. In the last 15 years peptide compounds with antihypertensive properties have been studied and received special attention. The main source of antihypertensive peptides comes from milk sources, but extraordinary findings have been obtained from other food sources, namely peas. Most pea peptides have demonstrated effectiveness in vitro, but more convincing evidence of antihypertensive effects must be based on animal experiments and clinical trials. ${ }^{6}$ The results of Aluko et al's study from Canada showed that pea protein hydrolysate powder can reduce hypertension and chronic kidney disease. In rats and humans with polycystic kidney disease the expenditure of urine is highly reduced, because the kidneys are unable to function as a filter for blood and fluid. In Aluko's study, rats given hydrolysate of yellow peas showed an increase in urine production by $30 \%$, blood pressure returned to normal levels beside that there were no visible side effects from the administration of pea protein hydrolysate in rats. ${ }^{7}$

The natural form of peas does not have effect as good as their hydrolysate, because the therapy effect is in their bioactive form of the peptide and this peptide needs to be released from the main protein through the process of breaking peptide bonds or hydrolysis by proteases so that the free peptides activated. The focus of further study is to find specific peptides in pea protein hydrolysate that have potency to be used as a treatment and prevention of CKD. ${ }^{8}$

In CKD patients whose protein intake is limited, need to be given special protein, that can be used without producing waste products that are toxic to the body. It would be very excellent if the provide protein can prevent glomerular fibrosis as well. The green peas protein hydrolysate which hydrolysed by bromelain (GPPHB), with small molecular weight, has been shown to have a promising effect on improving renal function. There has been done a lot of research and findings obtained about protein hydrolysate. Study results that have been proven need to be continuing developed and investigated. Green Peas Protein hydrolysate has a promising result to be a functional food or CKD Patients in the future.

\section{REFERENCES}

1. Miller. Protein hydrolysate. Miller, Seventh Edition. (C) 2003 by. In: Keane Encyclopedia and Dictionary of Medicine, Nursing, and Allied Health. Seventh. Saunders; 2003.

2. Clemente A. Enzymatic protein hydrolysates in human nutrition. Trends in Food Science and Technology. 2000.

3. Hariyadi P. Codex alimentarius and regulatory development for functional food. Presented at the: Bandung International Conference on Food and Health (BICFH) 2019. Intitut Teknologi Bandung, Indonesia. 2019.

4. Surono I. Exploration of biodiversity of lactic acid bacteria from curds: probiotics, prebiotics, microbiomas and functional food. Scientific Oration inauguration of professor. Bina Nusantara University. 2019.

5. Aluko RE. Antihypertensive Peptides from Food Proteins. Annual Review of Food Science and Technology. 2015.

6. Li H, Aluko RE. Identification and inhibitory properties of multifunctional peptides from pea protein hydrolysate. Journal of Agricultural and Food Chemistry. 2010.

7. Nieberler $M$, Reuning $U$, Reichart $F$, et al. Exploring the role of RGD-recognizing integrins in cancer. Cancers (Basel). 2017.

8. Goligorsky MS, Noiri E, Kessler H, Romanov V. Therapeutic potential of RGD peptides in acute renal injury. Kidney International. 1997. 